\section{Verification and Modification of a Model to Predict Bitter Pit for 'Honeycrisp' Apples}

\author{
Richard P. Marini \\ Department of Plant Science, The Pennsylvania State University, 203 Tyson \\ Building, University Park, PA 16802
}

Tara Auxt Baugher

The Pennsylvania State University, Cooperative Extension in Adams County, 670 Old Harrisburg Road, Gettysburg, PA 17325

\section{Megan Muehlbauer}

Rutgers New Jersey Agricultural Experiment Station, 314 State Route 12, Building 2, P.O. Box 2900, Flemington, NJ 08822-4102

\section{Sherif Sherif \\ Alison H. Smith Jr. Agricultural Research and Extension Center, 595 Laurel \\ Grove Road, Winchester, VA 22602}

Robert Crassweller

Department of Plant Science, The Pennsylvania State University, 7 Tyson Building, University Park, PA 16802

\section{James R. Schupp \\ Fruit Research and Extension Center, The Pennsylvania State University, 290 University Drive, Biglerville, PA 17307}

Additional index words. apple peel analysis, calcium disorder, Malus $\times$ domestica, mineral nutrition, prediction, postharvest disorder

\begin{abstract}
Honeycrisp' (Malus $\times$ domestica) apples were harvested from a total of 17 midAtlantic orchards during 2018 and 2019 to verify a previously published bitter pit prediction model. As in the previous study, bitter pit incidence was associated with low calcium (Ca) levels and high ratios of nitrogen $(\mathrm{N})$, potassium $(\mathrm{K})$, and/or magnesium (Mg) to $\mathrm{Ca}$ in the fruit peel and excessive terminal shoot growth. The best two-variable model for predicting bitter pit developed with the 2018-19 data set contained boron (B) and the ratio of $\mathrm{Mg}$ to $\mathrm{Ca}\left(R^{2}=0.83\right)$, which is different from previous models developed with data from three individual years $(2015-17)$. When used to predict the bitter pit incidence of the 2018-19 data, our previous best model containing the average shoot length (SL) and the ratio of $\mathrm{N}$ to $\mathrm{Ca}$ underestimated the incidence of bitter pit. The model is probably biased because one or more important variables related to bitter pit have not yet been identified. However, the model is accurate enough to identify orchards with a low incidence of bitter pit.
\end{abstract}

Received for publication 10 July 2020. Accepted for publication 9 Aug. 2020.

Published online 22 October 2020

This work is supported by the U.S. Department of Agriculture National Institute of Food and Agriculture and Hatch Appropriations under Project no. 4625 and Accession no. 1006805 , and the Pennsylvania Department of Agriculture Research Program.

We acknowledge the valuable contributions of Dan and Mark Boyer, Bennett Saunders, and Ben Keim (grower cooperators).

R.P.M. is the corresponding author. E-mail: rpm12@psu.edu.

This is an open access article distributed under the CC BY-NC-ND license (https://creativecommons. org/licenses/by-nc-nd/4.0/). disorders, including bitter pit (Al Shoffe et al., 2016; DeEll et al., 2016; Watkins et al., 2004). Several studies showed that bitter pit development is likely due to an imbalance of $\mathrm{K}, \mathrm{Mg}, \mathrm{P}, \mathrm{Ca}$, and $\mathrm{N}$ in the fruit (Cheng, 2016; Ferguson, 2001; Ferguson and Watkins, 1989). The severity of bitter pit varies considerably among years, orchards, and trees within orchards. During some years, $100 \%$ of the fruit on a tree may develop bitter pit after storage; often, more than $30 \%$ of the fruit develop bitter pit (Baugher et al., 2017). To avoid storing, packing, and shipping fruit that is likely to develop bitter pit, apple producers must be able to identify blocks of trees with high potential for bitter pit so they can sell the fruit immediately. We recently reported a bitter pit prediction model for 'Honeycrisp' based on the average shoot length (SL) and ratio of $\mathrm{N}$ to $\mathrm{Ca}$ in the peel of apples sampled 3 weeks before commercial harvest from individual trees with varying crop densities at six commercial orchards in Adams County, PA, over 3 years (Baugher et al., 2017). The model was validated using three different statistical methods that provided supporting evidence that the selected model included the most important variables that were evaluated. However, the model tended to underpredict bitter pit for trees with higher levels of observed bitter pit. The objective of this study was to obtain 'Honeycrisp' apples from blocks of trees, rather than individual trees, in a larger geographical region to verify the model.

\section{Materials and Methods}

During 2018 and 2019, bitter pit was assessed at eight and nine 'Honeycrisp' orchards, respectively (Table 1). For each orchard, 20 mature trees with crop loads that were representative of the block were selected; $\approx 3$ weeks before the anticipated harvest, three fruit were randomly sampled at $\approx 1.7 \mathrm{~m}$ aboveground from each tree for fruit peel tissue analysis, as previously described (Baugher et al., 2017). No indices of fruit maturity were measured. Although crop density was not recorded, the commercial growers indicated that the trees had moderate crop loads following chemical and hand thinning. Each fruit was washed and, using a potato peeler, a $1-\mathrm{cm}$ wide peel sample was removed from around the circumference at the calyx end of the fruit. Flesh tissue adhering to the peel was removed with a spoon. Fruit peel samples were dried for $4 \mathrm{~h}$ at $70{ }^{\circ} \mathrm{F}$ and sent to the Penn State Agricultural Analytical Services Laboratory, where they were ground and analyzed for N, P, $\mathrm{K}, \mathrm{Ca}, \mathrm{Mg}, \mathrm{Mn}, \mathrm{Fe}, \mathrm{Cu}, \mathrm{S}, \mathrm{B}, \mathrm{Al}, \mathrm{Na}$, and $\mathrm{Zn}$ (procedures described at http://agsci.psu.edu/ aasl/plant-analysis/plant-methods). Following terminal bud set, the average SL was estimated from five representative current season shoots per tree.

Five fruit per tree were collected at optimum maturity for long-term storage based on a ground color of pale yellow. The samples were stored in commercial cold rooms at $\approx 3.3{ }^{\circ} \mathrm{C}$. Fruit were assessed for the incidence of bitter pit after 4 months in storage plus $7 \mathrm{~d}$ at $20^{\circ} \mathrm{C}$.

\section{Statistical analysis}

Identifying the best subset of variables to include in multiple regression models is complicated and somewhat arbitrary. Therefore, the general five-step approach used in this study is outlined here and described in more detail for each data set.

1. Evaluate relationships among 20 potential regressor variables plus bitter pit incidence with scatter plots and correlation matrix 
Table 1. Description of orchards from which 'Honeycrisp' apples were sampled in 2018 and 2019, along with concentrations of phosphorus (P), potassium (K), and boron (B) and the nitrogen (N)-to-calcium (Ca) ratio in peel tissue, average shoot length (SL), and observed bitter pit and incidence of bitter pit predicted using the previously published model (Baugher et al., 2017).

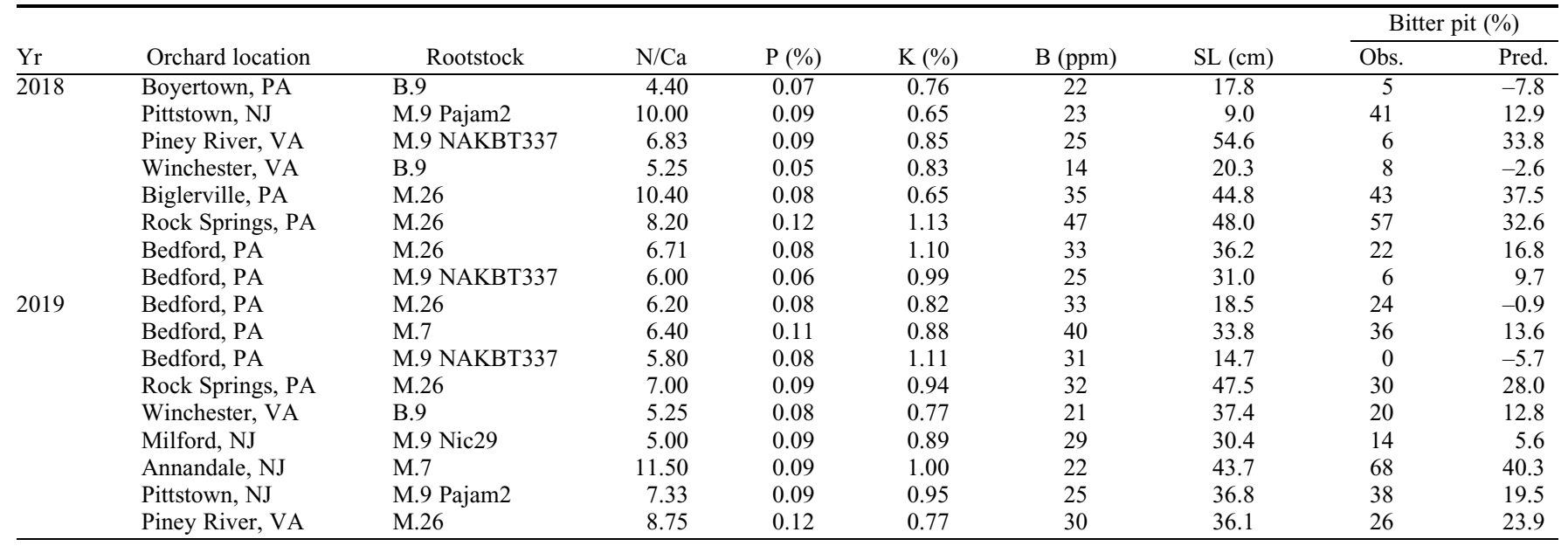

Table 2. The best one-, two-, three-, and four-variable multiple regression models for predicting the percentage of 'Honeycrisp' apples that will develop bitter pit after storage based on shoot length (SL; $\mathrm{cm}$ ) and peel nutritional concentrations (\%) sampled 3 weeks before harvest. Models were developed with the trial 1 data set (2015, 2016, and 2017; Baugher et al., 2017), with the trial 2 data set (2018 plus 2019), and with the combined data sets (2015-19). All $R^{2}$ values were significant $(P<0.0001)$. Except for phosphorus $(\mathrm{P})$ and boron $(\mathrm{B})$ in the data set for 2018 plus 2019, all regression coefficients were significant $(P<0.05)$.

\begin{tabular}{|c|c|c|c|c|c|c|c|}
\hline & Intercept & $\mathrm{N} / \mathrm{Ca}$ & SL & $P$ & $\mathrm{~B}$ & $R^{2}$ & $\operatorname{Adj} R^{2}$ \\
\hline \multicolumn{8}{|c|}{ Trial 1 data set for 2015, 2016, and $2017(n=161)$} \\
\hline $\mathrm{SE}$ of the estimates & 3.81 & 4.63 & - & - & - & & \\
\hline Parameter estimates & -54.91 & 3.77 & 0.75 & 186.2 & - & 0.692 & 0.676 \\
\hline SE of the estimates & 6.31 & 0.29 & 0.12 & 77.1 & - & & \\
\hline Parameter estimates & -46.82 & 4.17 & 0.58 & 363.3 & -0.78 & 0.712 & 0.634 \\
\hline Parameter estimates & -28.64 & 7.69 & - & - & - & 0.653 & - \\
\hline $\mathrm{SE}$ of the estimates & 10.68 & 1.45 & - & - & - & & \\
\hline Parameter estimates & -32.28 & 7.14 & $0.22^{\mathrm{Ns}}$ & - & - & 0.670 & 0.623 \\
\hline SE of the estimates & 10.18 & 1.73 & 0.34 & - & - & & \\
\hline Parameter estimates & -45.31 & 6.53 & $0.09^{\mathrm{Ns}}$ & $251.3^{\text {ns }}$ & - & 0.712 & 0.646 \\
\hline SE of the estimates & 13.53 & 1.74 & 0.36 & 169.8 & - & & \\
\hline Parameter estimates & -47.07 & 6.72 & $0.08^{\mathrm{Ns}}$ & $150.7^{\mathrm{Ns}}$ & $0.34^{\mathrm{Ns}}$ & 0.762 & 0.682 \\
\hline \multicolumn{8}{|c|}{ Combined data set for $2015-19(n=176)$} \\
\hline SE of the estimates & 3.72 & 0.28 & 0.11 & - & - & & \\
\hline Parameter estimates & -53.28 & 3.52 & 0.79 & 203.2 & - & 0.658 & 0.652 \\
\hline $\mathrm{SE}$ of the estimates & 6.66 & 0.27 & 0.11 & 74.5 & - & & \\
\hline Parameter estimates & -47.41 & 3.77 & 0.68 & 342.6 & -0.60 & 0.671 & 0.664 \\
\hline SE of the estimates & 6.44 & 0.28 & 0.11 & 91.2 & 0.23 & & \\
\hline
\end{tabular}

${ }^{\mathrm{z}}$ Regression coefficients with ${ }^{\mathrm{NS}}$ are not significant at the $5 \%$ level.

$\mathrm{N}=$ nitrogen; $\mathrm{Ca}=$ calcium.

2. Identify important regressor variables with four preliminary variable selection methods (forward, backward, stepwise, and Max. R-square regression)

3. Identify candidate models with linear predictor variables

a. Estimate the maximum number of variables to include in the model by plotting Mallow's conceptual predictive criterion $\left(C_{\mathrm{p}}\right)$ statistic against the number of predictor variables b. Use the "all possible regressions" approach to identify candidate models with subsets of predictor variables

c. Determine if quadratic or interaction terms improve the model

4. Identify and remove collinear variables and highly influential observations

5. Test assumptions of normality and variance homogeneity

Developing a predictive model with data from 2018 plus 2019. There were 20 potential regressor variables: $\mathrm{SL}, \mathrm{N}, \mathrm{P}, \mathrm{K}, \mathrm{Ca}, \mathrm{Mg}, \mathrm{S}$,
$\mathrm{Mn}, \mathrm{Fe}, \mathrm{B}, \mathrm{Cu}, \mathrm{Al}, \mathrm{Zn}, \mathrm{Na}, \mathrm{N} / \mathrm{Ca}, \mathrm{K} / \mathrm{Ca}, \mathrm{Mg} /$ $\mathrm{Ca},(\mathrm{Mg}+\mathrm{K}) / \mathrm{Ca},(\mathrm{Mg}+\mathrm{K}+\mathrm{N}) / \mathrm{Ca}\{[(\mathrm{Mg}+$ $\mathrm{K}) / \mathrm{Ca}+(\mathrm{N} / \mathrm{Ca})]-38$ (referred to as the accumulated ratio)\}. Relationships among the regressor variables were evaluated graphically as scatter plots with SAS PROC GPLOT, PROC SGSCATTER, and PROC G3D. PROC CORR (Freund and Littell, 2000) was used to generate a correlation matrix to evaluate the linear relationships between the response variable (percentage of fruit with bitter pit symptoms after storage) as well as the 20 potential regressor variables The accumulated ratio was included as a 
variable because it is used by Washington packers to segregate fruit by storage potential (developed by Harold Ostenson; Hanson, 2012). Based on the correlation and scatter plot matrices, six variables $(\mathrm{S}, \mathrm{Mn}, \mathrm{Fe}, \mathrm{Cu}$, $\mathrm{Al}$, and $\mathrm{Na}$ ) were discarded as nonimportant explanatory variables. The accumulated ratio was also discarded because it correlated perfectly $(r=1.0)$ with the less complicated variable $(\mathrm{N}+\mathrm{K}+\mathrm{Mg}) / \mathrm{Ca}$.

Candidate multiple regression models to predict bitter pit were identified using four options with SAS PROC REG (FORWARD selection, BACKWARD elimination, STEPWISE selection, and MAXR maximum $\mathrm{R}$-square improvement) by including the regressor variables $\mathrm{N}, \mathrm{P}, \mathrm{K}, \mathrm{Ca}, \mathrm{Mg}, \mathrm{B}$, and $\mathrm{SL}$. The five ratios of cations $[\mathrm{N} / \mathrm{Ca}, \mathrm{K} / \mathrm{Ca}, \mathrm{Mg} /$ $\mathrm{Ca},(\mathrm{K}+\mathrm{Mg}) / \mathrm{Ca}$ and $(\mathrm{N}+\mathrm{K}+\mathrm{Mg}) / \mathrm{Ca}$ ] were not included because they were highly correlated $(r>0.87)$ (Table 2). Although these model selection methods are easily performed and usually identify good models based on the selection criteria, they rarely identify the best model (Myers, 1990) because they ignore potential collinearity problems and fail to include variables involved in interactions. A plot of Mallow's $C_{\mathrm{p}}$ indicated that a model with five or fewer regressor variables would prevent overfitting the model. The model with all six individual elements plus SL had an $R^{2}=0.78$. The RSQUARE option was included in the model statement to generate all possible onevariable, two-variable, three-variable, and so on up to 12-variable models that included the six individual elements plus SL and five cation ratios. Criteria considered for model selection included the coefficient of determination $\left(R^{2}\right)$, adjusted $R^{2}$, Mallow's $C_{\mathrm{p}}$, mean square error, Akaike information criterion, Bayesian information criterion, and predicted sum of squares. A manual backward selection technique was used as a final method of developing a model. A multiple regression model was fit with all 12 predictor variables (six individual elements, SL, and five ratios). The variable with the largest $P$ value was deleted and the reduced model was fit. This process continued until only significant variables $(P<0.05)$ remained. Then, the INFLUENCE option in PROC REG was included in the model statement to generate variance inflation factors, tolerance indices, eigenvalues, condition indices, and proportion of variance values to identify and delete variables that were collinear.

Developing a model with the pooled data set for 5 years. Data used to develop the previously published model using data from 2015 to 2017 (Baugher et al., 2017) plus data from 2018 and 2019 were pooled $(\mathrm{n}=178)$, and the same process that was previously descried was used to develop a new model. After the final model was selected, two influential observations, based on DFFITS and Cook's D statistic, were deleted from the data set and the final model was developed using the data set with 176 observations.

Using data from nine individual trees at six orchards for 3 years, we previously iden- tified the best two-, three- and four-variable models for predicting bitter pit (Baugher et al., 2017). This original 3-year data set $(n=161)$ is referred to here as trial 1 . The data collected in 2018 and 2019 are referred to here as trial 2. One method of crossvalidation to graphically evaluate the predictive ability of a model is determining how well the bitter pit models from trial 1 estimate bitter pit for trial 2. The OUTEST option in PROC REG was used to produce the parameter estimates for the best one-, two-, and three-variable models using data from trial 1 , and PROC SCORE was used to calculate the estimated responses for trial 2 data.

\section{Results and Discussion}

Verification of published models. The regression models for trial 2 containing one, two, three, or four variables had similar $R^{2}$ values compared with the corresponding models developed with trial 1 data, and the regression coefficients were only slightly different (Table 2). The SE of the estimates were larger for models developed with trial 2 data, likely because there were only $\approx 10 \%$ as many observations for trial 2. Values of bitter pit incidence predicted with the two-, three-, and four-variable models were linearly related to observed values (Fig. 1). However, all three models were biased and underpredicted bitter pit, especially at the higher levels of observed bitter pit. A perfect relationship between predicted and observed bitter pit would have a slope of 1.0 and an $R^{2}=1.0$. Slopes and $R^{2}$ values were 0.55 and $0.52,0.63$ and 0.57 , and 0.59 and 0.54 , respectively, for the two-, three-, and fourvariable models. These results support our results from trial 1 using PROC SCORE, in which bitter pit values were underpredicted for trees with high levels of observed bitter pit (Baugher et al., 2017). Predictions were slightly better for the three- and four-variable models, but they still underpredicted the bitter pit incidence for 15 of the 17 orchards in trial 2. At low levels of bitter pit, the predicted values were only $\approx 5 \%$ too low; however, when observed bitter pit was $\approx 70 \%$, the predicted values were only $37 \%$ of the observed values. Al Shoffe et al. (2019) recently published a bitter pit prediction model based on a "passive method" reported by England and Larson (1973). The method involved sampling fruit 3 weeks before the anticipated harvest and holding the fruit at $20{ }^{\circ} \mathrm{C}$ to allow bitter pit to develop. The model based on the passive method also underpredicted bitter pit for 'Honeycrisp' fruit.

Developing a model with trial 2 data (2018 and 2019). For apples collected in 2018 and 2019, bitter pit incidence was positively and linearly related to $\mathrm{P}$ and all six cation ratios, and it was negatively related to $\mathrm{Ca}$ (Table 3). Ca and $\mathrm{P}$ were the only individual elements significantly correlated with bitter pit $(r>0.48)$; however, bitter pit was better correlated with all cation ratios $(r>$ $0.77)$. The six cation ratios were also highly
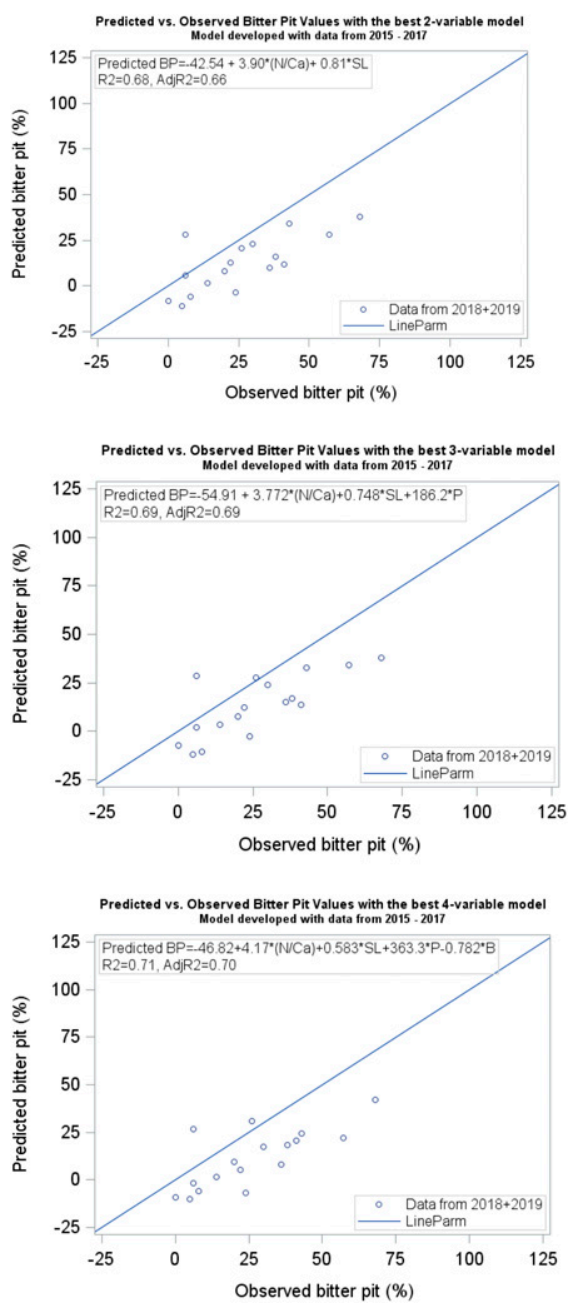

Fig. 1. Plots of the predicted incidence and observed incidence of bitter pit for trial 2 data collected in 2018 and 2019, using the best two-, three-, and four-variable models developed with data from 2015 and 2016 plus 2017 (trial 1 ). The 45 -degree line is the line of equality.

correlated with each other (Table 3). Scatter plots of raw data and residuals provided no evidence that the relationships between bitter pit and the predictor variables were curvilinear. SL was not correlated with any of the other 12 variables. $\mathrm{N}$ was positively correlated with $\mathrm{Mg}$ and $\mathrm{Ca}$. $\mathrm{K}$ was correlated with $\mathrm{Mg}, \mathrm{P}$, and $\mathrm{B}$. $\mathrm{Mg}$ was correlated with $\mathrm{N} / \mathrm{Ca}$, and $\mathrm{Ca}$ was correlated with all the ratios except N/Ca. Three of the ratios, $(\mathrm{K}+\mathrm{Mg}) /$ $\mathrm{Ca},(\mathrm{N}+\mathrm{K}+\mathrm{Mg}) / \mathrm{Ca}$, and the accumulated ratio, were nearly perfectly correlated $(r \geq$ $0.99)$. The best model with all significant $(P<$ $0.05)$ variables and no collinear terms was $B P$ $(\%)=-45.19+1.07 * \mathrm{~B}+18.89 *(\mathrm{Mg} / \mathrm{Ca})$, with $R^{2}=0.84$ and adjusted $R^{2}=0.81$. This model contains different regressor terms than the best models developed with data from 2015,2016 , or 2017 data sets and from the pooled (2015-17) data set. The results support our previous results (Baugher et al., 2017) indicating that the best predictive models for bitter pit incidence contained different predictor variables each year. When data from trial 1 were fit with the best model 
Table 3. Matrix of correlation coefficients to evaluate the linear relationships between bitter pit (\%) after storage and various concentrations (\%) of 'Honeycrisp' fruit peel elements measured 3 weeks before harvest in 2018 and 2019 ( $r$ values $>0.48$ and 0.61 are significant at the $5 \%$ and $1 \%$ levels, respectively; $\mathrm{n}=17$ ).

\begin{tabular}{|c|c|c|c|c|c|c|c|c|c|c|c|c|c|}
\hline Variable & Bitter pit & $\overline{\mathrm{SL}}$ & $\mathrm{N}$ & $\mathrm{K}$ & $\mathrm{Mg}$ & $\mathrm{Ca}$ & $\mathrm{P}$ & $\mathrm{B}$ & $\mathrm{Mg} / \mathrm{Ca}$ & $\mathrm{K} / \mathrm{Ca}$ & $\mathrm{N} / \mathrm{Ca}$ & $(\mathrm{K}+\mathrm{Mg}) / \mathrm{Ca}$ & $(\mathrm{N}+\mathrm{K}+\mathrm{Mg}) / \mathrm{Ca}$ \\
\hline$\overline{\mathrm{SL}}$ & 0.45 & - & - & - & - & - & - & - & - & - & - & - & - \\
\hline $\mathrm{N}$ & 0.09 & 0.30 & - & - & - & - & - & - & - & - & - & - & - \\
\hline K & 0.47 & 0.32 & 0.46 & - & - & - & - & - & - & - & - & - & - \\
\hline $\mathrm{Mg}$ & 0.41 & 0.39 & 0.77 & 0.53 & - & - & - & - & - & - & - & - & - \\
\hline $\mathrm{Ca}$ & -0.54 & -0.04 & 0.66 & 0.13 & 0.18 & - & - & - & - & - & - & - & - \\
\hline $\mathrm{P}$ & 0.55 & 0.45 & 0.12 & 0.61 & 0.36 & -0.26 & - & - & - & - & - & - & - \\
\hline B & 0.37 & 0.32 & 0.46 & 0.78 & 0.37 & 0.25 & 0.67 & - & - & - & - & - & - \\
\hline $\mathrm{Mg} / \mathrm{Ca}$ & 0.80 & 0.31 & -0.06 & 0.20 & 0.44 & -0.71 & 0.36 & -0.80 & - & - & - & - & - \\
\hline $\mathrm{K} / \mathrm{Ca}$ & 0.77 & 0.26 & -0.34 & 0.26 & 0.05 & -0.79 & 0.36 & -0.04 & 0.87 & - & - & - & - \\
\hline $\mathrm{N} / \mathrm{Ca}$ & 0.81 & 0.41 & 0.37 & 0.38 & 0.66 & -0.41 & 0.41 & 0.17 & 0.88 & 0.68 & - & - & - \\
\hline$(\mathrm{K}+\mathrm{Mg}) / \mathrm{Ca}$ & 0.78 & 0.27 & -0.32 & 0.26 & 0.09 & -0.79 & 0.37 & -0.04 & 0.89 & 0.99 & 0.70 & - & - \\
\hline$(\mathrm{N}+\mathrm{K}+\mathrm{Mg}) / \mathrm{Ca}$ & 0.82 & 0.31 & -0.20 & 0.29 & 0.21 & -0.75 & 0.39 & -0.01 & 0.93 & 0.98 & 0.80 & 0.99 & 0.99 \\
\hline Accum ratio & 0.82 & 0.31 & -0.20 & 0.29 & 0.21 & -0.75 & 0.39 & -0.01 & 0.99 & 0.98 & 0.80 & 0.99 & 1.00 \\
\hline
\end{tabular}

$\mathrm{B}=$ boron; $\mathrm{Ca}=$ calcium; $\mathrm{K}=$ potassium; $\mathrm{Mg}=$ magnesium; $\mathrm{N}=$ nitrogen; $\mathrm{P}=$ phosphorus; $\mathrm{SL}=$ shoot length.

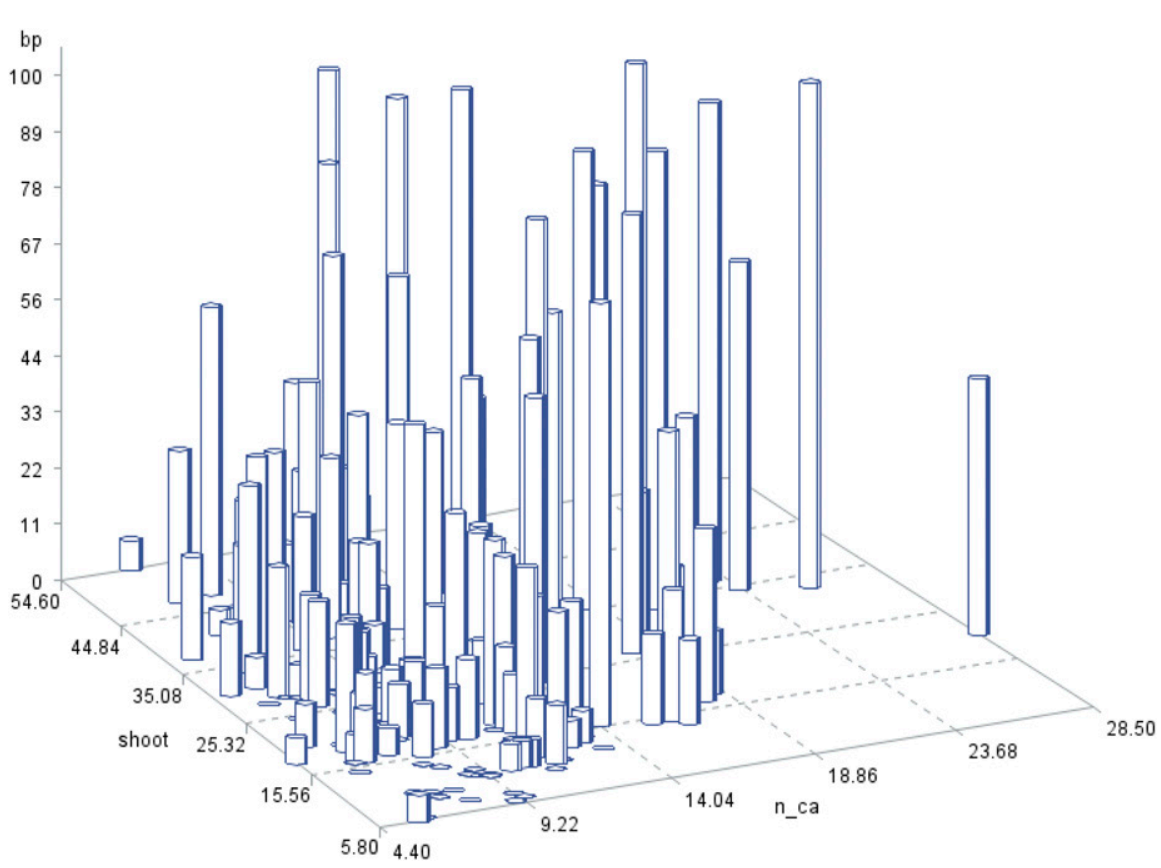

Fig. 2. Three-dimensional bar chart showing the incidence of bitter pit (\%) (bp) as shoot length (shoot) and that the nitrogen $(\mathrm{N})$-to-calcium $(\mathrm{Ca})$ ratio (n_ca) varied for the 5-year pooled data set.

from trial $2, R^{2}=0.49$ and bitter pit was underpredicted at low levels of observed bitter pit and overpredicted at high levels of observed bitter pit (data not shown).

Revising the model with 5 years of data. A three-dimensional plot for the 5-year data set showed that bitter pit incidence was low when shoots were short and when the N/Ca ratio was low, but there was quite a bit of variation in the data (Fig. 2). When the SL $\times(\mathrm{N} / \mathrm{Ca})$ interaction term was included in the model, it was not significant $(P=0.21)$ and it did not improve the predictive ability of the model.

Data from the two trials were combined and all possible regression models were requested with the RSQUARE option in PROC REG (Table 4). The same variables that were selected using data from trial 1 (Baugher et al., 2017) were again selected: the best one-variable model contained $\mathrm{N} / \mathrm{Ca}$, the best two-variable model contained $\mathrm{N} / \mathrm{Ca}$ and SL, the best three-variable model contained $\mathrm{N} / \mathrm{Ca}$, SL, and $\mathrm{P}$, and the best four- explained $55 \%$ of the variation in bitter pit incidence compared with $64 \%$ for the best model $(\mathrm{SL}+\mathrm{N} / \mathrm{Ca})$. The model without nitrogen not only explained less variation but also was more biased and overpredicted all observations, with bitter pit incidence greater than $45 \%$.

The fact that our best models and those previously published explain less than $70 \%$ of the variation in bitter pit incidence suggests that one or more important variables are missing from the models. Bitter pit is a complex disorder, and some important contributing factors may not have been identified yet. There may be several reasons why our best model explained only $67 \%$ of the variation in bitter pit incidence. It is possible that a single peel sample at 3 weeks before harvest does not fully represent the nutritional status of the fruit, and additional sampling times may be beneficial. Preliminary work showed that bitter pit could be predicted reasonably well from peel samples at 3 weeks before harvest. Additional sampling dates may improve the prediction, but it would also increase the expense. Taking samples later than 3 weeks before harvest may not allow enough time to obtain results for making marketing decisions.

In this study, fruit maturity was not assessed; however, for most cultivars, bitter pit is most severe in early picked fruit (Perring, 1986). We found this to be the case for 'Honeycrisp' in a preliminary experiment. Al Shoffe et al. $(2016,2020)$ recently discussed the development of bitter pit and soft scald during storage for conditioned and unconditioned fruit in relation to mineral contents and harvest indices. For unconditioned fruit sampled at the start of commercial harvest, bitter pit incidence was least severe for fruit with high internal ethylene concentration, low starch values, and high $\mathrm{Ca}$ concentrations in peel tissue. Bitter pit was most severe for fruit with green skin color $\left(I_{A D}\right)$ and high peel tissue $\mathrm{P}, \mathrm{K}, \mathrm{Mg}$, and cation ratios. 'Honeycrisp' is usually harvested based on ground color. However, ground color may not always be a good indicator of fruit maturity. Giacomo et al. (2017) recently evaluated the delta absorbance meter as a nondestructive method of predicting the ripening stage of 'Delicious' 
Table 4. The best four multiple regression models for one to four regressor variables along with fit statistics using data from single trees at six orchards for 3 years $(2015-17 ; \mathrm{n}=161)$ plus data from blocks of 20 trees in 2018 and $2019(\mathrm{n}=17)$. The pooled data set (trials 1 and 2$)$ had 175 observations.

\begin{tabular}{|c|c|c|c|c|c|c|}
\hline No. of variables & Model variables & $R^{2}$ & Adj. $R^{2}$ & $C_{\mathrm{p}}$ & $\overline{\mathrm{AIC}}$ & $\overline{M S E}$ \\
\hline \multirow{2}{*}{1} & $(\mathrm{~N}+\mathrm{K}+\mathrm{Mg}) / \mathrm{Ca}$ & 0.487 & 0.484 & 89.9 & 1061.4 & 384.3 \\
\hline & $(\mathrm{K}+\mathrm{Mg}) / \mathrm{Ca}$ & 0.438 & 0.435 & 115.4 & 1077.8 & 421.5 \\
\hline & $\mathrm{SL}+(\mathrm{N}+\mathrm{K}+\mathrm{Mg}) / \mathrm{Ca}$ & 0.597 & 0.592 & 35.4 & 1020.5 & 303.8 \\
\hline & $\mathrm{SL}+(\mathrm{K}+\mathrm{Mg}) / \mathrm{Ca}$ & 0.552 & 0.547 & 58.5 & 1039.3 & 337.7 \\
\hline & $\mathrm{SL}+\mathrm{Mg} / \mathrm{Ca}$ & 0.549 & 0.544 & 60.1 & 1040.6 & 340.1 \\
\hline & $\mathrm{SL}+(\mathrm{K}+\mathrm{MG}) / \mathrm{Ca}+(\mathrm{N}+\mathrm{K}+\mathrm{Mg}) / \mathrm{Ca}$ & 0.596 & 0.589 & 13.9 & 984.4 & 271.2 \\
\hline \multirow[t]{4}{*}{4} & $\mathrm{SL}+\mathrm{N} / \mathrm{Ca}+\mathrm{P}+\mathrm{B}$ & 0.622 & 0.613 & 4.5 & 975.1 & 255.6 \\
\hline & $\mathrm{SL}+\mathrm{N} / \mathrm{Ca}+\mathrm{P}+\mathrm{Ca}$ & 0.609 & 0.599 & 10.3 & 980.9 & 264.3 \\
\hline & $\mathrm{SL}+\mathrm{N} / \mathrm{Ca}+\mathrm{P}+\mathrm{Mg}$ & 0.608 & 0.598 & 10.8 & 981.5 & 265.1 \\
\hline & $\mathrm{SL}+(\mathrm{K}+\mathrm{Mg}) / \mathrm{Ca}+(\mathrm{N}+\mathrm{K}+\mathrm{Mg} / \mathrm{Ca})+\mathrm{P}$ & 0.607 & 0.598 & 11.0 & 981.6 & 265.4 \\
\hline
\end{tabular}

$\mathrm{AIC}=$ Akaike information criterion; $\mathrm{B}=$ boron $; \mathrm{Ca}=$ calcium; $C_{\mathrm{p}}=$ conceptual predictive criterion; $\mathrm{K}=$ potassium; $\mathrm{Mg}=$ magnesium; $\mathrm{MSE}=$ mean square error; $\mathrm{N}=$ nitrogen; $\mathrm{P}=$ phosphorus; $\mathrm{SL}=$ shoot length.

and 'Golden Delicious' apples. They harvested fruit at commercial maturity and recorded changes in commonly used indices of maturity (soluble solids concentration, flesh firmness, internal ethylene concentrations, and titratable acids) over a 4-week postharvest period at $20{ }^{\circ} \mathrm{C}$. The index of absorbance difference $\left(I_{A D}\right)$ that measures ground color was significantly and linearly associated with all four indices, but $R^{2}$ values ranged only from 0.22 to 0.72 . Based on the ratio performance deviation obtained by cross-validation, $I_{A D}$ values can be used to discriminate low values from high values of maturity indices, but course quantitative predictions were not possible. Prance et al. (2011) showed that bitter pit severity declined as 'Honeycrisp' apples became more mature, and few incidents bitter pit developed when fruit were harvested with a starch index of $\approx 5.4$ and internal ethylene concentration of $2.9 \mu \mathrm{L} \cdot \mathrm{L}^{-1}$. In a preliminary experiment with a sample of 20 'Honeycrisp' apples from each of three orchards, we found that $I_{A D}$ did not correlate well with the starch index because the relationship between $I_{A D}$ and starch varied with the orchard. Even within an orchard, individual fruits with $I_{A D}$ values of 0.66 could have starch index values of 1 to 7 (Marini, unpublished data). Ground color and starch index are unreliable as standalone indices of maturity, but they are the maturity indices most used by midAtlantic growers of 'Honeycrisp'. Currently, there is no reliable nondestructive measure of 'Honeycrisp' maturity, but inclusion of a such a variable in the model would likely enhance bitter pit prediction.

Fruit harvested from different canopy positions may vary in susceptibility to bitter pit. Calcium moves in the transpiration stream of trees; therefore, fruit developing in shade or parts of the canopy with low transpiration rates may have low calcium levels and a high incidence of bitter pit. Unexpectedly, concentrations of $\mathrm{Ca}$ and $\mathrm{K}$ in 'Cox's Orange Pippin' fruit in New Zealand were lower in fruit harvested from the upper parts of the tree than in fruit from the lower canopy, and the incidence of bitter pit increased from $12 \%$ in the lower parts to $24 \%$ in the upper parts of the canopy (Ferguson and Triggs, 1990). However, in a study using high-density orchards in Washington, Kalcsits et al. (2019) reported that 'Honeycrisp' apples from the upper canopy had higher concentrations of $\mathrm{Ca}$ and lower internal ethylene than fruit from the lower canopy. The K concentrations were similar regardless of canopy position. Only $14 \%$ of the fruit in the upper part of the canopy developed bitter pit compared with $31 \%$ in the lower canopy. Another factor that may influence bitter pit is crop load; Ferguson and Watkins (1992) found that fruit harvested from light-cropped trees had lower $\mathrm{Ca}$ and higher $\mathrm{K}$ concentrations as well as a higher incidence of bitter pit. They suggested that the ability to predict bitter pit from fruit $\mathrm{Ca}$ concentrations may be influenced by crop load. Fruit exposed to wind may have less bitter pit because high $\mathrm{Ca}$ concentrations of apple fruit and low levels of bitter pit were associated with increased wind speed (Lewis et al., 1977). The effect of canopy position may vary with environmental factors or orchard system because preliminary data from Pennsylvania suggest that the influence of canopy position on bitter pit severity may vary with orchard and year (unpublished data). Rootstocks influence vegetative vigor and nutrient uptake (Fazio et al., 2015). In the current study, trees on the more vigorous rootstocks (M.26 and M.7) had the highest incidence of bitter pit (Table 1). A group of researchers evaluating rootstocks in an NC-140 'Honeycrisp' trial are evaluating the influence of rootstock on fruit mineral concentrations and bitter pit, but unpublished preliminary results were inconsistent across locations and years within locations. As new models are developed to predict bitter pit, some of these variables should be considered.

Critical concentrations of various elements in apple fruit flesh have been related to bitter pit for several apple cultivars. Models for predicting bitter pit have been published for several apple cultivars based on $\mathrm{Ca}$ alone, or combinations of $\mathrm{Ca}$ plus $\mathrm{Mg}, \mathrm{B}$, $\mathrm{K}$, and/or $\mathrm{N}$, and $R^{2}$ values were typically less than 0.70 (Al Shoffe et al., 2019; Perring, 1986; Torres et al., 2017). The model based on the passive method $\left(R^{2}=0.68\right)$ also underpredicted bitter pit (Al Shoffe et al., 2019). To our knowledge, the current study is the first attempt to verify a bitter pit prediction model. Our best models explained less than $70 \%$ of the variation in bitter pit incidence and were biased, suggesting that models based on elemental levels in peel tissue, fruit weight, SL, and crop density will not accurately predict the incidence of bitter pit after storage. However, the model based on the passive method (Al Shoffe et al., 2019) and our model based on fruit peel analysis plus SL can be used to identify orchards with a relatively low risk $(<15 \%)$ of developing bitter pit after cold storage.

\section{Literature Cited}

Al Shoffe, Y.A., J.F. Nock, T.A. Baugher, R.P. Marini, and C.B. Watkins. 2020. Bitter pit and soft scald development during storage of unconditioned and conditioned 'Honeycrisp' apples in relation to mineral contents and harvest indices. Postharvest Biol. Technol. 160:111044.

Al Shoffe, Y.A., J.F. Nock, T.A. Baugher, and C. B. Watkins. 2016. Honeycrisp - to condition or not condition? New York Fruit Qrtly. 25(2):25-29.

Al Shoffe, Y.A., J.F. Nock, Y. Zhang, L. Zhu, and C.B. Watkins. 2019. Comparisons of mineral and nonmineral prediction methods for bitter pit in 'Honeycrisp' apples. Scientia Hort. 254:116-123.

Baugher, T.A., R. Marini, J.R. Schupp, and C.B. Watkins. 2017. Prediction of bitter pit in 'Honeycrisp' apples and best management implications. HortScience 52:1367-1374.

Cheng, L. 2016. Challenges and opportunities for Honeycrisp nutrient management. Proc. Empire State Expo. 15 June 2017.

DeEll, J.R., G.B. Lum, and B. Ehsani-Moghaddam. 2016. Effects of delayed controlled atmosphere storage on disorder development in 'Honeycrisp' apples. Can. J. Plant Sci. 96:621-629.

England, D.H. and F.E. Larson. 1973. Relation between pre and post-harvest bitter pit of 'Goldspur' and 'Wellspur' apples. Fruit Var. J. 27:27-29.

Fazio, G., L. Chang, M.A. Grusak, and T.L. Robinson. 2015. Apple rootstocks influence mineral nutrient concentration or leaves and fruit. N.Y. Qrtly. 23(2):11-15. 
Ferguson, I. 2001. Calcium in apple fruit. Proc. WA Tree Fruit Postharvest Conf., Wenatchee, WA. 15 June 2017.

Ferguson, B. and C.M. Triggs. 1990. Sampling factors affecting the use of mineral analysis of apple fruit for the prediction of bitter pit. New Zealand Crop Hort. Sci. 18:147-152.

Ferguson, I.B. and C.B. Watkins. 1989. Bitter pit in apple fruit. Hort. Rev. 11:289-355.

Ferguson, I.B. and C.B. Watkins. 1992. Crop load affects mineral concentrations and incidence of bitter pit in 'Cox's Orange Pippin' apple fruit. J. Amer. Soc. Hort. Sci. 117:373-376.

Freund, R.J. and R.C. Littell. 2000. SAS system for regression. 3rd ed. SAS Inst., Inc., Cary, NC.

Giacomo, C., R. Beghi, I. Mignani, and A. Spinardi. 2017. Nondestructive apple ripening stage determi- nation using the Delta absorbance meter at harvest and after storage. HortTechnology 27:54-64.

Hanson, M. 2012. Learn how to store Honeycrisp. Good Fruit Grower. 15 June 2017. <http:/ www.goodfruit.com/learn-to-store-honeycrisp/>.

Kalcsits, L., J. Mattheis, L. Giordani, M. Reid, and K. Mullin. 2019. Fruit canopy positioning affects fruit calcium and potassium concentrations, disorder incidence, and fruit quality for Honeycrisp' apple. Can. J. Plant Sci. 99:761-771.

Lewis, T.L., D. Martin, J. Cerny, and D.A. Ratkowsky. 1977. The effects of a sheltered environment on the mineral element composition of Merton Worcester apple fruits and leaves and on the incidence of bitter pit at harvest. J. Hort. Sci. 52:401-407.

Myers, R.H. 1990. Classical and modern regression with applications. 2nd ed. PWS-Kent, Boston, MA.
Perring, M.A. 1986. Incidence of bitter pit in relation to the calcium content of apples: Problems and paradoxes, a review. J. Sci. Food Agr. 37:591-606.

Prance, R., J. Delong, D. Nichols, and P. Harrison. 2011. Effect of fruit maturity on the incidence of bitter pit, senescent breakdown, and other post-harvest disorders of 'Honeycrisp' apple. J. Hort. Sci. Biotechnol. 86:245-248.

Torres, E., I. Recasens, G. Avila, J. Lordan, and S. Alegre. 2017. Early stage fruit analysis to detect a high risk of bitter pit in 'Golden Smoothee'. Scientia Hort. 219:98-106.

Watkins, C.B., J.F. Nock, S.A. Weis, S. Jayanty, and R.M. Beaudry. 2004. Storage temperature, diphenylamine, and pre-storage delay effects on soft scald, soggy break-down and bitter pit of 'Honeycrisp' apples. Postharv. Biol. Technol. 32:213-221. 